\title{
Chemical Composition and Antimicrobial Activity Against Food Poisoning of Alcoholic Extract of Nigella Sativa L
}

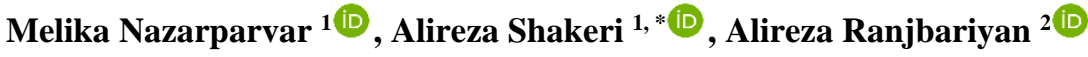 \\ 1 School of Chemistry, College of Science, University of Tehran, Tehran, Iran \\ 2 Department of Laboratories, Health Center of Tehran University of Medical Sciences, Tehran, Iran \\ * Correspondence: alireza.shakerl@ut.ac.ir;
}

Scopus Author ID57197226439

Received: 29.03.2020; Revised: 24.05.2020; Accepted: 25.05.2020; Published: 1.06.2020

\begin{abstract}
Nowadays using natural sources for treating disease is one of the most favorable methods because of fewer side effects. Reporting antimicrobial properties of a new natural source can be useful for designing new natural medicines antimicrobial effect of Nigella Sativa L. seeds n-butanol extract will be useful for treating or preventing for many infections. In our study we report the first GC-MS analysis of n-butanol extract of Nigella Sativa $L$. seed and also its antimicrobial activity against some food poisoning and nosocomial infection causing microorganisms. Nigella Sativa L. seed powder was subjected to n-butanol with ratio 1:10 in a flask and then kept on shaker. After filtering, the extract has been analyzed by GC-MS. After that, the extract was tested against bacteria and fungi by three method, disc diffusion, well diffusion, and micro dilution methods. The GC-MS analysis revealed that fatty acids and terpenoids are the major constituents. The result showed that pseudomonas aureoginosa, klebsiella pneumoniae, acinetobacter baumanii, Yersinia enterocolitica, Candida albicans, Candida parapsilosis and Candida krusei were the sensitive microorganisms. According to great antimicrobial activity and having nourishing components (fatty acids and terpenoids) adding this plant to a daily food diet is a good way for having a healthy life and this plant can be a new source for therapeutic uses.
\end{abstract}

Keywords: Nigella Sativa L; GC-MS analysis; antimicrobial; food diet.

(C) 2020 by the authors. This article is an open access article distributed under the terms and conditions of the Creative Commons Attribution (CC BY) license (https://creativecommons.org/licenses/by/4.0/).

\section{Introduction}

Nigella Sativa L. is an annual flowering plant in the family Ranunculaceae. It's native to Turkey, Pakistan and Iran [1]. Nigella Sativa seeds, a medicinal herb frequently known as black seed and its oil has been used for their medicinal, aromatic or flavoring properties since ancient times in different civilizations[2]. Traditionally, Nigella Sativa L. seeds extract has several beneficial biological effects including diuretic, diaphoretic, stomachic, liver tonic and digestive. It's also had been used in leucoderma, alopecia, eczema, freckles and pimples and also had been used as antibacterial and antioxidant [3]. Previous studies on Nigella sativa L. premiered $6 \%$ moisture, $4 \%$ ash, $32 \%$ fat $20 \%$ crude protein. Also it has been showing some minerals like Magnesium, Calcium, potassium, sodium and Iron [4]. Nigella Sativa seed essential oil that has been extracted by Clevenger apparatus, Microwave and steam distillation method, revealed the essential oil contains lots of the bioactive compound as the terpenoids that the main compound is Thymoquinone, a monoterpenoid ketone that has magnificent properties [5-7]. Oil composition of Nigella Sativa L. seed showed both saturated and unsaturated fatty acids, that two kinds of necessary fatty acids $\alpha$-linolenic acid (ALA) - an omega 3 fatty acid and linoleic acid (LA) - an omega 6 fatty acid are the main ones [8-9]. 
Different solvent extracts of Nigella Sativa L. seed contain both terpenoids and fatty acids [910]. Food poisoning (Foodborne disease) that is defined as a disease of infectious caused by food, is one of the major concerns worldwide. Food borne infections are caused by many different disease-causing pathogens that can contaminate foods, while food borne poisoning is caused by poisonous chemicals or harmful substance that are present in food. Some of the major food poisoning organisms are Salmonella typhimurium, Staphylococcus aureus, bacillus cereus, clostridium botulinum and Escherichia Coli [11]. Yersinia enterocolitica is one of the gram negative bacteria that is belonging to Enterobacteriaceae and recovered from animal and environmental reservoirs [12-13]. This organism acquired by insufficiently cooked meat or contaminated milk, water, fish and meat [14]. Yesinia enterocolitica is thought to be a significant food-borne pathogen, recently have been reported that is one of the food poisoning organism in Japan [14]. Hospital-acquired infections (HAI) or nosocomial infections encompass almost all clinically evident infections that do not originate from patients original admitting diagnosis. Nosocomial infections are one of the leading causes of death and increased recovery and force additional cost to health care systems [16]. Causative agents of nosocomial infections can be (by order of importance) different types of bacteria, fungi, viruses and parasites. Among the bacteria, Escherichia coli, Staphylococcus aureus ,Klebsiella pneumoniae and Acenitobacter baumannii are the most common and antibiotic resistance bacteria[17]. Pseudomonas aeruginosa as the cause of infection in burn centers are used in the present study [18]. Among fungi Candida albicans, Candida tropicalis, Candida krusei, Candida glabrata and Candida parapsilosis can cause nosocomial infections in patients who are somehow immunocompromised [19]. Due to drug resistance of agents causing nosocomial infections and many side effects of conventional synthetic antibiotics [20-21], nowadays many researchers work on finding new natural compounds as alternatives to synthetic drugs, since using natural and herbal drugs have fewer side effects and will enhance the quality of treatment [22]. In previous studies about solvent extracts of Nigella Sativa L. seeds, there was no report of GC-MS analysis of n-butanol extracts. There were just two qualitative reports about categories of chemical compounds in the extracts and there was nothing about the details of these compounds [23-24]. In this study the compounds of n-butanol extract of Nigella Sativa $L$. seeds by GC-MS analysis and also its antimicrobial properties against some food poisoning and nosocomial infection causing microorganisms in order to introduce this new plant as a rich source of nutritional components and new natural medicine for treating disease. Also, scientific evidence of traditional uses has been investigated.

\section{Materials and Methods}

\subsection{Collection of Nigella Sativa L. Seeds.}

Nigella Sativa seeds were purchased from local herb shop in Tehran, Iran. The plant species was confirmed and a voucher was deposited at herbarium of faculty of pharmacy, Tehran University of medical science (pmp-747).

\subsection{Extract preparation.}

The Nigella Sativa seeds were dried at ambient temperature and the seed were grinded into fine powder by electric grinder. Nigella Sativa L. seed powder was subjected to n-butanol with ratio 1:10 in a flask and then kept on shaker at room temperature on continuous shaking for one week. The extract then filtered through whatman filter paper 1 . The filtrated extract 
then dried in a rotary evaporator until all the solvent gets evaporated. Then the extract was stored at $4{ }^{\circ} \mathrm{C}$ for further research uses [24-25].

\subsection{GC-MS analysis.}

The chemical composition of the extracted seed was analyzed by GC-MS using an Agilent network system (GC: $6890 \mathrm{~N}$; MSD: $5973 \mathrm{~N}$ ). MS source temperature was $230^{\circ} \mathrm{C}$ and MS quad temperature was $150{ }^{\circ} \mathrm{C}$. The chromatographic column for the analysis was a TRB5 capillary column $(60 \mathrm{~m} \times 320 \mu \mathrm{m}$ id, film thickness of $0.5 \mu \mathrm{m})$. Helium was used as carrier gas at a flow rate of $1 \mathrm{ml} / \mathrm{min}$. The injection was performed in split $1: 1$ mode at $280{ }^{\circ} \mathrm{C}$. The extract was injected and analyzed with the column held initially at $40{ }^{\circ} \mathrm{C}$ for 5 minutes and then increased to $280{ }^{\circ} \mathrm{C}$ with a $10{ }^{\circ} \mathrm{C} / \mathrm{min}$ heating ramp and subsequently kept at $280{ }^{\circ} \mathrm{C}$ for 5 minutes.

\subsection{Microbial Studies.}

\subsubsection{Collection of strains.}

The antimicrobial activities, nosocomial infection causing were studied using selected bacteria: Pseudomonas aeruginosa (ATCC 27853), Klebsiella pneumoniae (ATCC BAA1706), Acinetobacter Baunmannii (ATCC BAA-747), food poisoning bacteria Escherichia Coli (ATCC 25922 ), Staphylococcus aureus ( ATCC 25923), Yersinia Enterocolitica ( ATCC 9610 ) and nosocomial infection causing fungi Candida albicans (PFCC 89-1078), Candida tropicalis (PFCC 90-797), Candida krusei (PFCC 89-840), Candida glabrata (PFCC 80-3033) and Candida parapsilosis (PFCC 90-1248). These Microorganismswere obtained from Pasteur institute of Iran

\subsubsection{Preparing microorganism, extract's samples and antibiotics.}

To prepare pure colonies of bacteria, each of them was passaged in nutrient agar separately and the plates were incubating for 24 hours at $35^{\circ} \mathrm{C}$. For preparing a pure colony of fungi, a passage from each type of them was performed in Sabouraud agar and the plates were incubated at $35^{\circ} \mathrm{C}$ for 48 hours. The test samples were prepared by dissolving $1.5,2$, and 2.5 $\mu 1$ of extract in $1 \mathrm{ml}$ of dimethyl sulfoxide (DMSO) solvent (Merck number: 317275).

Two antibiotics; Gentamicin and Amphotericin B were considered in bacteria and fungi plates as positive control respectively. Using DMSO solvent and adding the powder of antibiotics, concentration of Gentamicin was adjusted to $10 \mu \mathrm{g} / \mathrm{ml}$ and for Amphotericin B concentration was adjusted to $50 \mu \mathrm{g} / \mathrm{ml}$.

\subsubsection{Antimicrobial properties.}

Agar well diffusion method: For studying antimicrobial properties, from pure colony of microorganisms a suspension was prepared in the vials containing sterile normal saline and turbidity of the suspension was compared with $0.5 \mathrm{McFarland}$ standard by visual comparison (a $0.5 \mathrm{McF}$ arland standard is prepared by mixing $0.05 \mathrm{ml}$ of $1.175 \%$ barium chloride dehydrate with $9.95 \mathrm{ml}$ of $1 \%$ sulfuric acid). In this way, the cell density is about $1 \times 108 \mathrm{CFU} / \mathrm{ml}$ per vial. Mueller-Hinton medium is a standard environment for antibiogram. Therefore, each suspension was inoculated on plate $(10 \mathrm{~cm}$ in diameter) containing Mueller-Hinton agar for bacteria and Mueller-Hinton agar with $2 \%$ glucose for fungi by sterile swab, and 
microorganisms spread throughout the media. 5 wells, each with $5 \mathrm{~mm}$ diameter, $5 \mathrm{~mm}$ depth and $2.5 \mathrm{~mm}$ apart, were made with a puncher and to close the bottom of wells, $25 \mu 1$ molten Mueller-Hinton agar was poured at a temperature of $50^{\circ} \mathrm{C}$ In liquid form. After cooling, depth of wells is closed with a thickness of $1 \mathrm{~mm}$ Mueller-Hinton agar .in wells no. 1 to no. $3,100 \mu \mathrm{l}$ of the extract at concentrations 1500, 2000 and $2500 \mathrm{ppm}(1.5,2$ and $2.5 \mu 1 / \mathrm{ml})$ was added respectively. In well no. 4 of each plate, $100 \mu 1$ of antibiotic was added as positive control (Gentamicin for bacteria and Amphotericin B for fungi) and in well no. 5, $100 \mu 1$ DMSO was added as negative control. Bacteria plates were incubated for 24 hours and fungi plates for 48 hours in $37^{\circ} \mathrm{C}$. For each organism the process was repeated three times and the means and standard deviations of inhibition zone diameter were calculated.

Disk diffusion method: Sterilized Petri dishes $(10 \mathrm{~cm}$ diameter) already poured with nutrient agar media were inoculated with $0.01 \mathrm{~mL}$ of nutrient agar media (105 - 106 bacteria per ml). Discs injected with extract of different concentrations 1500, 2000 and 2500 ppm (1.5, 2 and $2.5 \mu \mathrm{l} / \mathrm{ml}$ ) and were applied on the solid agar medium by pressing tightly. One disc of

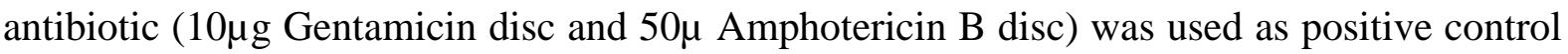
and one disc is injected with DMSO as negative control. The treated Petri dishes were incubated at $37^{\circ} \mathrm{C}$ for 24 hours for bacteria and 48 hours for fungi. The process was repeated three times for each microorganisms. At the end of the period, the antimicrobial activity was expressed as the mean diameter of the inhibition zone $(\mathrm{mm})$ produced by plant extracts.

Micro dilution method: In addition to good diffusion and disc diffusion technique, minimal inhibitory concentration (MIC) for bacteria and fungi was calculated. Micro dilution method was used for this study so that 7 columns in 96-well plate were chosen for seven microorganisms that show sensitivity to the compounds in the extract. $1 \mu 1$ of Muller-Hinton agar broth was added to all wells, and then $1 \mu 1$ of suspension containing $8 \mu \mathrm{l}$ of the extract dissolved in $1 \mathrm{ml}$ of DMSO after being filtered by a $0.2 \mu \mathrm{m}$ diameter microbiological filter, was added to all wells in the first row. With this account, concentration of the extract in well no. 1 of each microorganism was regulated as $4 \mu 1 / \mathrm{ml}(4000 \mathrm{ppm}) .6$ serial dilutions were made from wells no. 1 to $6(4,2,1,0.5,0.25,0.125 \mu \mathrm{l} / \mathrm{ml})$. Each well was inoculated with $20 \mu \mathrm{l}$ of the microorganism suspension similar to $0.5 \mathrm{McFarland}$ standards. For positive control for each microorganism, a well containing the microorganism and the culture was made in a 96 well microliter plate and incubated at $35^{\circ} \mathrm{C}$. After 24 hours for bacteria and 48 hours for yeasts, the MIC was read as the lowest concentration of an antimicrobial that will inhibit the visible growth of a microorganism after incubation

\section{Results and Discussion}

\subsection{GC-MS analysis.}

The n-butanol extract of Nigella Sativa seeds was identified by comparing their retention time with those of a computer library (Wiley 7n.l). The result of GC-MS analysis is presented in (table 1).

The major component of fatty acids was Linoleic acid $(26.156 \%)$ followed by $\alpha$ linolenic acid (21.268\%) and Linolelaidic acid (6.538\%) and the major components of terpenoids were o-cymene (7.452\%) and Thymoquinone $(6.753 \%)$. In a previous study about compounds of n-butanol extract of Nigella Sativa L. seeds, the extract's qualitative analysis of secondary metabolites showed that terpenoids are the main compounds [24]. Also in this study among the secondary metabolites, terpenoids are the main ones. Compared to other solvent 
extracts and essential oil of Nigella Sativa L. seeds, Thymoquinone was one of the main components. Among the terpenoids of n-butanol extract, unlike other extracts, o-Cymene $(7.452 \%)$ was more than Thymoquinone $(6.753 \%)$ [1, 5, 10]. Among the fatty acids that are found in other extracts and essential oil, Linoleic acid (omega 6) and $\alpha$-linolenic acid ((ALA) (omega 3) were the main unsaturated fatty acids and also have been observed in n-butanol extract as the main ones [4, 9-10]. In n-butanol extract of Nigella Sativa L. seed one unsaturated fatty acid, Linolelaidic acid, has been observed that had not been reported from other extracts and essential oil before. Linolelaidic acid (LA) is a geometric isomer of Linoleic acid. They both are an omega 6 fatty acid but linoleic acid is cis-omega 6 and linolelaidic acid is transomega 6 fatty acid (Figure 1). Previous studies on Linolelaidic acid revealed that this unsaturated fatty acid has anti-inflammatory and cancer protective activity [26]. Also, it's been revealed that Daniella Oliveri seed oil that contains $56.57 \%$ Linolelaidic acid showed great antibacterial activity against Klebsiella granulomatis [27].

Table 1. Chemical composition of n-butanol extract of $N$. sativa analyzed by GC-MS.

\begin{tabular}{l|c|c|c} 
Compound & Retention time $(\mathbf{m i n})$ & Area $(\%)$ & RI \\
\hline$\alpha$-thujene & 13.47 & $0.332 \%$ & 931 \\
\hline Sabinene & 14.52 & $0.183 \%$ & 976 \\
\hline Butanoic acid & 14.72 & $2.064 \%$ & 1002 \\
\hline o-cymene & 15.37 & $7.452 \%$ & 1027 \\
\hline$\gamma$-terpinene & 15.88 & $0.801 \%$ & 1062 \\
\hline Terpinen-4-ol & 16.96 & $0.900 \%$ & 1177 \\
\hline Thymoquinone & 19.06 & $6.753 \%$ & 1249 \\
\hline Carvacrol & 19.77 & $3.350 \%$ & 1298 \\
\hline$\alpha$-longipinene & 20.66 & $0.195 \%$ & 1343 \\
\hline Isolongifolene & 21.53 & $2.360 \%$ & 1402 \\
\hline $2,4-$ ditert-butylphenol & 23.17 & $4.310 \%$ & 1512 \\
\hline 2,3 -dihydrofarnesol & 24.61 & $0.194 \%$ & 1604 \\
\hline$\gamma$-eudesmol & 26.02 & $2.034 \%$ & 1646 \\
\hline Lauric acid & 27.52 & $4.980 \%$ & 1786 \\
\hline Palmitic acid & 28.45 & $1.278 \%$ & 1884 \\
\hline Myristic acid & 28.78 & $3.572 \%$ & 1977 \\
\hline Sandaracopimaradiene & 29.24 & $5.280 \%$ & 1980 \\
\hline Linolelaidic acid & 29.40 & $6.538 \%$ & 1982 \\
\hline Linoleic acid & 31.16 & $26.156 \%$ & 2076 \\
\hline$\alpha$-linolenic acid & 33.73 & $21.268 \%$ & 2116
\end{tabular}

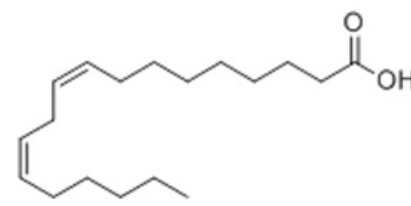

Linoleic acid<smiles>CCCCC/C=C/C/C=C/CCCCCCCC(=O)O</smiles>

Linolelaidic acid

Figure 1. Cis-linoleic acid and trans-linolelaidic acid.

According to this research it can be concluded that the presence of Linolelaidic acid might be the reason for amazing antimicrobial activity of n-butanol extract of Nigella Sativa L. seed. Unsaturated fatty acids help to lower levels of total cholesterol and LDL cholesterol in the blood [28]. Nigella Sativa $L$. is a rich source of unsaturated fatty acids (according to table 1 about $54 \%$ of unsaturated fatty acids). So, Nigella Sativa L. n-butanol extract can be used for controlling total and LDL cholesterol in the blood. Interest in medicinal plants has grown due 
to increased efficiency of new plant-derived drugs and the interest in natural products [29]. Plants were long used for curing infections also several plant products were documented to inhibit growth of pathogenic bacteria [30].

\subsection{Antimicrobial properties.}

Examining the plates after incubation in agar well diffusion and disc diffusion method, confirmed the inhibitory effect of the extract in all three concentrations on bacteria Pseudomonas aeruginosa, Klebsiella pneumoniae, Acinetobacter Baunmannii and Yersinia Enterocolitica and also fungi Candida albicans, Candida krusei and Candida parapsilosis (table 2 and table 3). No inhibition of growth was observed for other microorganisms. Also for controls, No inhibition zone around wells containing DMSO and the disc that is injected with DMSO (negative control) was observed and when using antibiotics (Gentamicin for bacteria and Amphotericin B for fungi as positive control) inhibition zones $10-13 \mathrm{~mm}$ for bacteria and 5-10 $\mathrm{mm}$ for fungi were observed.

Table 2. Antimicrobial activity of Nigella Sativa L. n-butanol extract by well diffusion method.

\begin{tabular}{|c|c|c|c|c|c|}
\hline \multirow[t]{2}{*}{ Microorganisms } & \multicolumn{3}{|c|}{ Concentration of extract } & \multirow{2}{*}{$\begin{array}{l}\text { DMSO (negative } \\
\text { control) } \\
(\mathrm{mm})\end{array}$} & \multirow{2}{*}{$\begin{array}{c}\text { Antibiotics } \\
\text { (positive control) } \\
(\mathrm{mm})\end{array}$} \\
\hline & $\begin{array}{c}1500 \mathrm{ppm} \\
(1.5 \mu \mathrm{l} / \mathrm{ml}) \\
(\mathrm{mm}) \\
\end{array}$ & $\begin{array}{c}2000 \mathrm{ppm} \\
(2 \mu \mathrm{l} / \mathrm{ml}) \\
(\mathrm{mm}) \\
\end{array}$ & $\begin{array}{c}2500 \mathrm{ppm} \\
(2.5 \mu 1 / \mathrm{ml}) \\
(\mathrm{mm}) \\
\end{array}$ & & \\
\hline $\begin{array}{l}\text { pseudomonas } \\
\text { aeruginosa }\end{array}$ & $41 \pm 0.3$ & $46 \pm 0.1$ & $50 \pm 0.2$ & 0 & $11 \pm 0$ \\
\hline Klebsiella & $20 \pm 0.2$ & $21 \pm 0.1$ & $23 \pm 0.2$ & 0 & $13 \pm 0$ \\
\hline Pneumonia & $31 \pm 0.1$ & $33 \pm 0.2$ & $35 \pm 0.2$ & 0 & $12 \pm 0$ \\
\hline $\begin{array}{l}\text { Acinetobacter } \\
\text { Baunmannii } \\
\end{array}$ & - & - & - & 0 & $10 \pm 0$ \\
\hline Escherichia Coli & - & - & - & 0 & $12 \pm 0$ \\
\hline $\begin{array}{l}\text { Staphylococcus } \\
\text { aureus }\end{array}$ & $28 \pm 0.2$ & $32 \pm 0.2$ & $35 \pm 0.2$ & 0 & $13 \pm 0$ \\
\hline $\begin{array}{l}\text { Yersinia } \\
\text { Enterocolitica }\end{array}$ & $30 \pm 0.4$ & $37 \pm 0.3$ & $41 \pm 0.6$ & 0 & $9 \pm 0$ \\
\hline Candida albicans & - & - & - & 0 & $7 \pm 0$ \\
\hline $\begin{array}{l}\text { Candida } \\
\text { tropicalis }\end{array}$ & $20 \pm 0.3$ & $22 \pm 0.1$ & $24 \pm 0.2$ & 0 & $5 \pm 0$ \\
\hline Candida krusei & - & - & - & 0 & $10 \pm 0$ \\
\hline Candida glabrata & $22 \pm 0.3$ & $25 \pm 0.3$ & $26 \pm 0.4$ & 0 & $7 \pm 0$ \\
\hline
\end{tabular}

a. Gentamicin $(10 \mu \mathrm{g} / \mathrm{ml})$ for bacteria and Amphotericin B $(50 \mu \mathrm{g} / \mathrm{ml})$ for fungi

Table 3. Antimicrobial activity of Nigella Sativa L. n-butanol extract by disc diffusion method.

\begin{tabular}{|c|c|c|c|c|c|}
\hline \multirow[t]{2}{*}{ Microorganisms } & \multicolumn{3}{|c|}{ Concentration of extract } & \multirow{2}{*}{$\begin{array}{l}\text { DMSO (negative } \\
\text { control) } \\
(\mathrm{mm})\end{array}$} & \multirow{2}{*}{$\begin{array}{c}\text { Antibiotics }^{\mathrm{a}} \\
\text { (positive control) } \\
(\mathrm{mm})\end{array}$} \\
\hline & $\begin{array}{c}1500 \mathrm{ppm} \\
(1.5 \mu \mathrm{l} / \mathrm{ml}) \\
(\mathrm{mm}) \\
\end{array}$ & $\begin{array}{c}2000 \mathrm{ppm} \\
(2 \mu \mathrm{l} / \mathrm{ml}) \\
(\mathrm{mm})\end{array}$ & $\begin{array}{c}2500 \mathrm{ppm} \\
(2.5 \mu 1 / \mathrm{ml}) \\
(\mathrm{mm}) \\
\end{array}$ & & \\
\hline Pseudomonas aeruginosa & $60 \pm 0.2$ & $40 \pm 0.3$ & $40 \pm 0.1$ & 0 & $11 \pm 0$ \\
\hline Klebsiella pneumonia & $50 \pm 0.2$ & $46 \pm 0.3$ & $46 \pm 0.2$ & 0 & $13 \pm 0$ \\
\hline Acinetobacter Baunmannii & $48 \pm 0.1$ & $50 \pm 0.2$ & $47 \pm 0.4$ & 0 & $12 \pm 0$ \\
\hline Escherichia Coli & - & - & - & 0 & $10 \pm 0$ \\
\hline Staphylococcus aureus & - & - & - & 0 & $12 \pm 0$ \\
\hline Yersinia Enterocolitica & $40 \pm 0.2$ & $39 \pm 0.3$ & $38 \pm 0.1$ & 0 & $13 \pm 0$ \\
\hline Candida albicans & $42 \pm 0.3$ & $27 \pm 0.2$ & $22 \pm 0.2$ & 0 & $9 \pm 0$ \\
\hline Candida tropicalis & - & - & - & 0 & $7 \pm 0$ \\
\hline Candida krusei & $10 \pm 0.1$ & $15 \pm 0.2$ & $11 \pm 0.1$ & 0 & $5 \pm 0$ \\
\hline Candida glabrata & - & - & - & 0 & $10 \pm 0$ \\
\hline Candida parapsilosis & $30 \pm 0.2$ & $25 \pm 0.1$ & $30 \pm 0.3$ & 0 & $7 \pm 0$ \\
\hline
\end{tabular}

a. Gentamaicin for bacteria and amphotericin B for fungi

The results of MIC for sensitive microorganisms are shown in (table 4). Compared to other sensitive microorganisms, Candida albicans and Yersinia Enterocolitica have higher sensitivity in smaller doses. 
Table 4. Minimum inhibitory concentration (MIC) of microorganisms sensitive to n-butanol extract of Nigella Sativa L. seeds.

\begin{tabular}{l|l} 
Microorganism & $\mathbf{M I C} \boldsymbol{\mu l} / \mathrm{ml}(\mathbf{p p m})$ \\
\hline pseudomonas aeruginosa & $0.5 \mu \mathrm{l} / \mathrm{ml}(500 \mathrm{ppm})$ \\
\hline Klebsiella pneumoniae & $0.25 \mu \mathrm{l} / \mathrm{ml}(250 \mathrm{ppm})$ \\
\hline Acinetobacter Baunmannii & $1 \mu \mathrm{l} / \mathrm{ml}(1000 \quad \mathrm{ppm})$ \\
\hline Yersinia Enterocolitica & $0.125 \quad \mu \mathrm{l} / \mathrm{ml} \quad(125$ \\
& $\mathrm{ppm})$ \\
\hline Candida albicans & $0.125 \quad \mu \mathrm{l} / \mathrm{ml} \quad(125$ \\
& $\mathrm{ppm})$ \\
\hline Candida krusei & $0.25 \mu \mathrm{l} / \mathrm{ml}(250 \mathrm{ppm})$ \\
\hline Candida parapsilosis & $0.5 \mu \mathrm{l} / \mathrm{ml}(500 \mathrm{ppm})$
\end{tabular}

Compared to previous study about antimicrobial activity of n-butanol extract of Nigella Sativa L. seeds, the antimicrobial activity of n-butanol extract have been studied against bacteria Enterococcus faecalis, Staphylococuss aureus, Acinetobacter junii, Escherichia coli, Proteus mirabilis, Serratia marcescens and Enterobacter cloacae [24]. The n-butanol extract of Nigella Sativa seeds have not been tested against Klebsiella pneumoniae, Acenitobacter baumannii, Pseudomonas aeruginosa, Yersinia enterocolitica and fungi Candida albicans, Candida tropicalis, Candida krusei, Candida glabrata and Candida parapsilosis for antimicrobial activity, so this research is the first report of antimicrobial activity against these microorganism for n-butanol extract of Nigella Sativa L. seeds. According to previous studies of other extracts and essential oil of Nigella Sativa L. seeds, essential oil of Nigella Sativa L. seeds showed antimicrobial activity against Staphylococuss aureus, Pseudomonas aeruginosa, Escherichia coli, Klebsiella pneeumoniae and Candida albicans [5,8]. Ethanol extract showed antimicrobial activity against Escherichia coli, Staphylococcus aureus, Candida albicans [2526]. Methanol extract showed antimicrobial activity against Staphylococuss aureus, Pseudomonas aeruginosa, Escherichia coli, Klebsiella pneeumoniae and Candida albicans [24, 31-32]. Aqueous, chloroform and acetone extract showed antibacterial activity against bacteria Staphylococuss aureus, Pseudomonas aeruginosa, Escherichia coli, Klebsiella pneumoniae and also acetone extract showed antifungal activity against Candida albicans [24, 25, 31-32]. For other microorganisms that have been studied in this research, previous studies have shown that essential oil of Nigella Sativa seed has antibacterial activity against Yersinia enterocolitica [33] but against Acinetobacter baumannii the essential oil was insensitive [34]. Against fungi Candida krusei, Candida tropicalis the SFE extracted volatile oil of Nigella Sativa L. seed showed antifungal activity [35] and also it has been reported that Candida glabrata, Candida tropicalis and Candida parapsilosis were sensitive to Nigella Sativa seed essential oil [36].

Yersinia enterocolitica is one of the most important food poisoning causing organisms around the world. This organism is responsible for milk, meat, pork, seafood, water, vegetables poisoning. It's been reported that this organism can survive at low temperature [37-38]. So finding a natural source to control this organism is an amazing achievement. Nigella Sativa L. seed n-butanol extract showed a great antibacterial effect against Yersinia enterocolitica ( 28 to $40 \mathrm{~mm}$ inhibition zone). According to this result, using this plant's extract can be effective for restraining the infections that are caused by Yersinia enterocolitica.

Given the prevalence of nosocomial infections among patients in hospitals [39], especially in immunocompromised patients [40], identification of suitable herbal antimicrobial compounds can make the course of treatment more favorable. Acinetobacter genus commonly causes nosocomial infections [41]. Acinetobacter baumannii is one of the most common and multidrug resistant microorganism [42] and the leading organism of infection in almost every 
ICU, especially in emergency, neurosurgery ICU's and respiratory tract infections [43-44]. Klebsiella pneumoniae is the other multidrug resistant [45], blood stream infection and surgical site infection causing organism [43]. Pseudomonas aeruginosa is the other organism that causes bloodstream infection and respiratory tract infections [43]. Candida is a genus of yeast and is the most common cause of fungal infection around the world [46]. Candida spp. Can cause lots of fungal nosocomial infection, such as urinary tract infection, especially Candida albicans [43, 47]. Candida krusei is associated with hematological unit infections and it has a high risk of mortality [48]. It has been found that Candida parapsilosis is the most common organism in onychomycosis (nail infection) and Candidemia in hospitals [49-50]. According to the results obtained in present study Nigella Sativa L. seed n-butanol extract displayed magnificent inhibition against these nosocomial infection causing bacteria and fungi. So it can be a new source to control these infections for patients in hospitals during their treatment. Since the plant-derived compounds cause fewer side effects [51-52], they can be a good alternative to synthetic antibiotics. Having great antimicrobial activity of this plant can be evidence for traditional uses of this plant as antibacterial agent.

\section{Conclusions}

Antimicrobial effect of n-butanol extract of Nigella Sativa L. seed on nosocomial infections causing organisms and food poisoning causing organism is quite interesting. Since the extract has great antimicrobial activity, Nigella Sativa L. seed n-butanol extract can be used besides antibiotics to increase the treatment ability. Linolelaidic acid is one of the fatty acids that have been found in this extract and this compound has not been studied independently, therefore separation of Linolelaidic acid from fatty acids in the extract and further investigations are recommended. Also, it is recommended to study fatty acids and terpenoids of this extract independently, because it has been studied in a mixture and it is a question that they would show better biological activity independently or in a mixture. Also, it is suggested to use Nigella Sativa L. seed in a daily food diet for a more healthy life, because of having unsaturated fatty acids and terpenoids, it can help to improve body's health.

\section{Funding}

This research received no external funding.

\section{Acknowledgments}

The authors are very thankful to the University of Tehran for financially supporting this study. The authors also gratefully acknowledge the role played by Keyvan Borzoo during sampling and transportation of samples.

\section{Conflicts of Interest}

The authors declare no conflict of interest.

\section{References}

1. Longato, E.; Meineri, G.; Peiretti, P.G. Nutritional and zootechnical aspects of Nigelia sativa: A review. Journal of Animal and Plant Sciences 2015, 25, 921-934.

2. Yimer, E.M.; Tuem, K.B.; Karim, A.; Ur-Rehman, N.; Anwar, F. Nigella sativa L.(black cumin): a promising natural remedy for wide range of illnesses. Evidence-Based Complementary and Alternative Medicine 2019, https://doi.org/10.1155/2019/1528635. 
3. Gilani, A.U.H.; Jabeen, Q.; Khan, M.A.U. A review of medicinal uses and pharmacological activities of Nigella sativa. Pak J Biol Sci 2004, 7, 441-445, https://doi.org/10.1016/S2221-1691(13)60075-1.

4. Nergiz, C.; Ötleş, S. Chemical composition of Nigella sativa L. seeds. Food chemistry 1993, 48, 259-261, https://doi.org/10.1016/0308-8146(93)90137-5.

5. Gerige, S.J.; Gerige, M.K.Y.; Rao, M. GC-MS Analysis of Nigella sativa seeds and antimicrobial activity of its volatile oil. Brazilian Archives of Biology and Technology 2009, 52, 1189-1192, https://doi.org/10.1590/S1516-89132009000500016.

6. Mukhtar, H.; Qureshi, A.S.; Anwar, F.; Mumtaz, M.W.; Marcu, M. Nigella sativa L. seed and seed oil: potential sources of high-value components for development of functional foods and nutraceuticals/pharmaceuticals. Journal of Essential Oil Research 2019, 31, 171-183, https://doi.org/10.1080/10412905.2018.1562388.

7. Islam, M.T.; Khan, M.R.; Mishra, S.K. An updated literature-based review: phytochemistry, pharmacology and therapeutic promises of Nigella sativa L. Orient Pharm Exp Med. 2019, 19, 115-129, https://doi.org/10.1007/s13596-019-00363-3.

8. Khan, M.A. Chemical composition and medicinal properties of Nigella sativa Linn. Inflammopharmacology 1999, 7, 15-35, https://doi.org/10.1007/s10787-999-0023-y.

9. Subratti, A.; Lalgee, L.J.; Jalsa, N.K. Efficient extraction of black cumin (Nigella sativa L.) seed oil containing thymol, using liquefied dimethyl ether (DME). Journal of Food Processing and Preservation 2019, 43, e13913, https://doi.org/10.1111/jfpp.13913.

10. Singh, G.; Marimuthu, P.; de Heluani, C.S.; Catalan, C. Chemical constituents and antimicrobial and antioxidant potentials of essential oil and acetone extract of Nigella sativa seeds. Journal of the Science of Food and Agriculture 2005, 85, 2297-2306, https://doi.org/10.1002/jsfa.2255.

11. Le Loir, Y.; Baron, F.; Gautier, M. Staphylococcus aureus and food poisoning. Genet Mol Res 2003, 2, 6376.

12. Kapatral, V.; Olson, J.W.; Pepe, J.C.; Miller, V.L.; Minnich, S.A. Temperature-dependent regulation of Yersinia enterocolitica Class III flagellar genes. Molecular microbiology 1996, 19, 1061-1071, https://doi.org/10.1046/j.1365-2958.1996.452978.x.

13. Karimi, Z.; Alizadeh, A.M.; Dolatabadi, J.E. N.; Dehghan, P. Nigella sativaand its Derivatives as Food Toxicity Protectant Agents. Advanced pharmaceutical bulletin 2019, 9, 22, https://doi.org/10.15171/apb.2019.004.

14. Terentjeva, M.; Eizenberga, I.; Valciņa, O.; Novoslavskij, A.; Strazdina, V.; Bērziňš, A. Prevalence of Foodborne Pathogens in Freshwater Fish in Latvia. Journal of Food Protection 2015, 78, 2093-2098, https://doi.org/10.4315/0362-028X.JFP-15-121.

15. Sakai, T.; Nakayama, A.; Hashida, M.; Yamamoto, Y.; Takebe, H.; Imai, S. Outbreak of food poisoning by Yersinia enterocolitica serotype $\mathrm{O} 8$ in Nara prefecture: the first case report in Japan. Japanese journal of infectious diseases 2005, 58, 257.

16. Hassan, M.; Tuckman, H.P.; Patrick, R.H.; Kountz, D.S.; Kohn, J.L. Cost of hospital-acquired infection. Hospital topics 2010, 88, 82-89, https://doi.org/10.1080/00185868.2010.507124.

17. Rice, L.B. Federal funding for the study of antimicrobial resistance in nosocomial pathogens: no ESKAPE. Journal of Infectious Diseases 2008, 197, 1079-1081, https://doi.org/10.1086/533452.

18. Azimi, L.; Motevallian, A.; Ebrahimzadeh Namvar, A.; Asghari, B.; Lari, A.R. Nosocomial infections in burned patients in Motahari hospital, Tehran, Iran. Dermatology research and practice 2011, 2011, https://doi.org/10.1155/2011/436952.

19. De Cassia Orl, J.; de Souza Pitangui, N.; Gullo, P.; e Maria, A.M.F.A.; Giannini, J.S.M. A mini review of Candida species in hospital infection: epidemiology, virulence factor and drugs resistance and prophylaxis. Tropical Medicine and Surgery 2013, 1-7, https://doi.org/10.4172/2329-9088.1000141.

20. Archibald, L.; Phillips, L.; Monnet, D.; McGowan, J.E.; Tenover, F.; Gaynes, R. Antimicrobial resistance in isolates from inpatients and outpatients in the United States: increasing importance of the intensive care unit. Clinical Infectious Diseases 1997, 24, 211-215, https://doi.org/10.1093/clinids/24.2.211.

21. Gudiol, C.; Carratalà, J. Antibiotic resistance in cancer patients. Expert review of anti-infective therapy 2014, 12, 1003-1016, https://doi.org/10.1586/14787210.2014.920253.

22. Iwata, S.; Akita, H. Adverse effects of antibiotics. Pediatrics International 1997, 39, 143-154, https://doi.org/10.1111/j.1442-200x.1997.tb03571.x.

23. Amutha, K.; Godavari, A. Antidiabetic and phytochemical screening of Nigella sativa. Journal of Chemical and Pharmaceutical Research 2015, 7, 432-436.

24. Ishtiaq, S.; Ashraf, M.; Hayat, M.Q.; Asrar, M. Phytochemical analysis of Nigella sativa and its antibacterial activity against clinical isolates identified by ribotyping. Int J Agri Biol 2013, 15, 1151-1156.

25. Zahra, N.; Jahan, N.; Nosheen, S.; Rehman, K. Antimicrobial activity of aqueous, ethanolic extracts and crude extracted phytoconstituents of Nigella sativa seeds. Biosci Res 2011, 8, 19-25.

26. Chaudhary, R.; Tripathy, A. Isolation and identification of bioactive compounds from Irpex Lacteus Wild Fleshy Fungi. J. Pharm. Sci. Res 2015, 7, 424-434.

27. Atolani, O.; Olabiyi, E.T.; Issa, A.A.; Azeez, H.T.; Onoja, E.G.; Ibrahim, S.O.; Zubair, M.F.; Oguntoye, O.S.; Olatunji, G.A. Green synthesis and characterisation of natural antiseptic soaps from the oils of 
underutilised tropical seed. Sustainable Chemistry and Pharmacy 2016, 4, 32-39, https://doi.org/10.1016/j.scp.2016.07.006.

28. DiNicolantonio, J.J. O'Keefe, J.H. Effects of dietary fats on blood lipids: a review of direct comparison trials. Open Heart 2018, 5, e000871, https://doi.org/10.1136/openhrt-2018-000871.

29. Harzallah, H.J.; Kouidhi, B.; Flamini, G.; Bakhrouf, A.; Mahjoub T. Chemical composition, antimicrobial potential against cariogenic bacteria and cytotoxic activity of Tunisian Nigella sativa essential oil and thymoquinone. Food Chemistry 2011, 129, 1469-1474, https://doi.org/10.1016/j.foodchem.2011.05.117.

30. Emeka, L.B.; Emeka, P.M. and Khan, T.M. Antimicrobial activity of Nigella sativa L. seed oil against multi-drug resistant Staphylococcus aureus isolated from diabetic wounds. Pakistan journal of pharmaceutical sciences 2015, 28, 1985-1990.

31. Nawahwi, M. Z.; Ab Malek, H. Antimicrobial activity of Nigella sativa seed extract. Sains Malaysiana 2013, 42, 143-147.

32. Tanıs, H.; Aygan, A.; Digrak, M. Antimicrobial activity of four Nigella sp. species grown in southern Turkey. International Journal of Agriculture and Biology 2009, 11, 771-774.

33. Arici, M.; Sagdic, O.; Gecgel, U. Antibacterial effect of Turkish black cumin (Nigella sativa L.) oils. Grasas y Aceites 2005, 56, 259-262, https://doi.org/10.3989/gya.2005.v56.i4.90.

34. Salman, M.T.; Khan, R.A.; Shukla, I. Antimicrobial activity of Nigella sativa Linn. Seed oilagainst multidrug resistant bacteria from clinical isolates, Antimicrobial activity of Nigella sativa Linn. Seed oilagainst multi-drug resistant bacteria from clinical isolates. Natural product Radiance 2008, 7, 10-14.

35. Piras, A.; Rosa, A.; Marongiu, B.; Porcedda, S.; Falconieri, D.; Dessì, M.A.; Ozcelik, B.; Koca, U. Chemical composition and in vitro bioactivity of the volatile and fixed oils of Nigella sativa L. extracted by supercritical carbon dioxide. Industrial Crops and Products 2013, 46, 317-323, https://doi.org/10.1016/j.indcrop.2013.02.013.

36. Rath, C.C.; Mohapatra, S. Susceptibility characterisation of Candida spp. to four essential oils. Indian journal of medical microbiology 2015, 33, 93, https://doi.org/10.4103/0255-0857.150903.

37. Bottone, E.J. Yersinia enterocolitica: revisitation of an enduring human pathogen. Clinical Microbiology Newsletter 2015, 37, 1-8, https://doi.org/10.1016/j.clinmicnews.2014.12.003.

38. Sirghani, K.; Zeinali, T.; Jamshidi, A. Detection of Yersinia enterocolitica in retail chicken meat, Mashhad, Iran. Journal of pathogens 2018, 2018, https://doi.org/10.1155/2018/1286216.

39. Marshall, S.H.; Arenas, G. Antimicrobial peptides: A natural alternative to chemical antibiotics and a potential for applied biotechnology. Electronic Journal of Biotechnology 2003, 6, 271-284, https://doi.org/10.2225/vol6-issue3-fulltext-1.

40. Jarvis, W.R.; Martone, W.J. Predominant pathogens in hospital infections. Journal of Antimicrobial Chemotherapy 1992, 29, 19-24, https://doi.org/10.1093/jac/29.suppl_A.19.

41. Wong, D.; Nielsen, T.B.; Bonomo, R.A.; Pantapalangkoor, P.; Luna, B.; Spellberg, B. Clinical and pathophysiological overview of Acinetobacter infections: a century of challenges. Clinical Microbiology Reviews 2017, 30, 409-447, https://doi.org/10.1128/CMR.00058-16.

42. Viana, G.F.; dos Santos Saalfeld, S.M.; Garcia, L.B.; Cardoso, C.L.; Pelisson, M.; Tognim, M.C.B. Evolution of antimicrobial resistance of Acinetobacter baumannii in a university hospital. Letters in applied microbiology 2011, 53, 374-378, https://doi.org/10.1111/j.1472-765X.2011.03109.x.

43. Gecgel, S.K.; Demircan, N. The epidemiology of pathogen microorganisms in hospital acquired infections. International Journal of Clinical and Experimental Medicine 2016, 9, 22310-22316.

44. Yue, D.; Song, C.; Zhang, B.; Liu, Z.; Chai, J.; Luo, Y.; Wu, H. Hospital-wide comparison of health careassociated infection among 8 intensive care units: A retrospective analysis for 2010-2015. American Journal of Infection Control 2017, 45, e7-e13, https://doi.org/10.1016/j.ajic.2016.10.011.

45. Bassetti, M.; Righi, E.; Carnelutti, A.; Graziano, E.; Russo, A. Multidrug-resistant Klebsiella pneumoniae: challenges for treatment, prevention and infection control. Expert review of anti-infective therapy 2018, 16, 749-761, https://doi.org/10.1080/14787210.2018.1522249.

46. Cortegiani, A.; Misseri, G.; Fasciana, T.; Giammanco, A.; Giarratano, A.; Chowdhary, A. Epidemiology, clinical characteristics, resistance, and treatment of infections by Candida auris. Journal of intensive care 2018, 6, 69, https://doi.org/10.1186/s40560-018-0342-4.

47. Martins, N.; Ferreira, I.C.; Barros, L.; Silva, S.; Henriques, M. Candidiasis: Predisposing factors, prevention, diagnosis and alternative treatment. Mycopathologia 2014, 177, 223-240, https://doi.org/10.1007/s11046014-9749-1.

48. Hautala, T.; Ikäheimo, I.; Husu, H.; Säily, M.; Siitonen, T.; Koistinen, P.; Kujala, P. A cluster of Candida krusei infections in a haematological unit. BMC infectious Diseases 2007, 7, 97, https://doi.org/10.1186/1471-2334-7-97.

49. Pinhati, H.M.S.; Casulari, L.A.; Souza, A.C.R.; Siqueira, R.A.; Damasceno, C.M.G.; Colombo, A.L. Outbreak of candidemia caused by fluconazole resistant Candida parapsilosis strains in an intensive care unit. BMC infectious diseases 2016, 16, https://doi.org/10.1186/s12879-016-1767-9.

50. Singh, A.; Masih, A.; Khurana, A.; Singh, P.K.; Gupta, M.; Hagen, F.; Meis, J.F.; Chowdhary, A. High terbinafine resistance in Trichophyton interdigitale isolates in Delhi, India harbouring mutations in the squalene epoxidase gene. Mycoses 2018, 61, 477-484, https://doi.org/10.1111/myc.12772. 
51. Othman, L.; Sleiman, A.; Abdel-Massih, R.M. Antimicrobial Activity of Polyphenols and Alkaloids in Middle Eastern Plants. Frontiers in microbiology 2019, 10, 911. https://doi.org/10.3389/fmicb.2019.00911.

52. Savoia, D. Plant-derived antimicrobial compounds: alternatives to antibiotics. Future microbiology 2012, 7, 979-990, https://doi.org/10.2217/fmb.12.68. 